\title{
Ownership Structure and Efficiency of Banking Industry in China and Vietnam - A Political View
}

\author{
Manh-Trung Phung ${ }^{1}$, Cheng-Ping Cheng ${ }^{1} \&$ Chen-Yu Kao ${ }^{1}$ \\ ${ }^{1}$ Department of Finance, National Yunlin University of Science and Technology, Taiwan, R.O.C \\ Correspondence: Cheng-Ping Cheng, Assoc. Prof., Department of Finance, National Yunlin University of Science \\ and Technology. 123 University Road, Section 3, Douliou 64002, Yunlin, Taiwan, R.O.C. Tel: 886-952-453-336.
}

Received: May 6, 2018

Accepted: May 28, 2018

Online Published: June 5, 2018

doi:10.5430/ijfr.v9n3p61

URL: https://doi.org/10.5430/ijfr.v9n3p61

\begin{abstract}
Ownership structure and the performance of banking industry have been long considered as a matter of debate. Despite of differences in perspective, both "development view" and "politics view" approve the desire of governments to control financial institutions through their ownership structure. This paper adopts the two-stage stochastic frontier analysis (SFA) to examine the relation between ownership structure and bank's efficiency in two long historic communism countries - China and Vietnam with the consideration of some political factors. Our result consistently indicates that banks with foreign-controlled shareholders in both countries can increase their efficiency significantly. Additionally, we uncover an interesting phenomenon that is during the election years, state-owned banks in China and Vietnam outperform the others. These banks are also the most beneficiaries from the economic expansion. Finally, meta-frontier is utilized to compare the relative performance of banking industry in these two countries.
\end{abstract}

Keywords: ownership, politics, schochastic frontier, cost efficiency

\section{Introduction}

Banking industry may differ from other traditional business, though its contribution to the determination of long-run economic growth is conspicuous (Pradhan, et al., 2014). Therefore, policymakers, investors and even world financial institutions have been encouraged to investigate the efficiency and productivity of banking industry. Along with the studies pursuing the approaches of efficiency estimation, recent researches have led to a renewed interest in exploring factors that would impact a bank's performance. A considerable amount of cross-sectional studies suggests an association between bank's efficiency and exogenous determinants, such as risks, internationalization, or corporate governance.

Inasmuch as governance structure (or ownership structure) refers to the distribution of rights and obligations among variety participants of the enterprises, it will theoretically influence the rules and processes of decisions making for corporate issues, and therefore the final performance. On the other hand, in the perspective of macroeconomists, ownership structure reflects both political system and freedom of financial market (Lin, et al., 2016). Most of them concur that governments generally manipulate the operations of state-owned financial institutions, which play a critical role in the economy, in order to achieve political purposes. For instance, Dinç (2005) found that in emerging markets, there is a considerable lending increase per government-owned bank per election, which indicates how politicians direct those banks with the intention of allocating the rents to their supporters. In other word, state-owned banks (SOBs), to a certain extended can be partially considered as an instrument that is of assistance for political purposes (Jackowicz et al., 2013). Obviously, there is a need for deliberate consideration of political environment in order to fully comprehend the role of banks in financial system.

China and Vietnam are two long-historic communism countries whose banking industries operate under various governmental regulations. The performances of their SOBs, who are directed by the ruling parties, are still ambiguous across countries. This derives from an argument about the main target of those SOBs that is whether they serve as an instrument to support project funds for political purposes, make profit or serve as public service (Baum, et al., 2010). This paper aims to examine the impact of politics - ownership nexus toward banking industry in these two countries. There are few researches closely related to this topic, for instance, Micco et al. (2007); Jackowicz et al. (2013). Differ from previous researches that use some proxies to present for bank's performance, we employ a 
two-stage stochastic frontier analysis (SFA) proposed by Battese and Coelli (1995) to simultaneously evaluate the technical efficiency of banking industries in China and Vietnam as well as the influence of exogenous variables to those efficiencies. Finally, a stochastic meta-frontier is utilized to compare the relative efficiency these two banking industries. Due to the lack of understanding about financial mechanism in the communism countries in respect of political perspective, this research, to a certain extent, will enrich the existing literature and shed light on future research direction.

\section{Literature Review}

\subsection{Bank's Performance and Political Perspective}

The participation of government in financial markets has been long considered as a matter of debate. Traditional literatures have experienced two broadest views - that are "development (or optimism) view" and "politics view". The first view advocated the state ownership of firms in vital economic areas, particularly banking industry, is the key element for the success of economic development. Even though private banks have been the crucial intermediation of distributing savings into industries, it was not, in general, sufficient for the development of economic institutions (Stiglitz, 1993). On the other hand, despite the fact that "politics view" also approves the desire of government to control financial institutions, it demonstrates that this manipulation is often due to negatively political reasons, such as benefiting for partisans, rather than social purposes (Frydman, et al., 1999).

Within the last two decades, research questions usually involve with comparing the performance of state and private ownership as well as exploring the motivation of government as the participant in the economy. La Porta et al. (2002) indicated that this ownership accounts for a large portion and dominates in countries, which have low income ratio, old-fashion financial systems, inefficiency governments, and less protection for property rights. Beck et al. (2004) implied that the more state ownership increase, the worse banks perform in term of productivity, and therefore, slow down the development of financial industry. It is even worse from the result of Caprio and Peria (2000) that banking crises are more likely due to the greater manipulation of government in banks. These researches apparently expressed no concession with the social view. Conversely, there are still few investigators who have the positive eyes with the importance of government institutions. Andrianova et al. (2012) evidence a higher long-run growth is robustly connected with the government ownership of banks, and hence suggested a need for deliberation of privatize government owned banks. To a certain extent, some researchers believe that, in addition to the degree of economic freedom, political connections can benefit bank's performance and are potentially more valuable to banks (Gropper et al., 2015).

Being considered as an emerging market under communism political system, the economy of China has attracted many curiostities of scholars. Regarding the lending activities of banking system, most of studies suggest a significant relation between politically connected banks and politically connected firms to gain private benefits and thus increase the probability of a crisis (Hung et al., 2017; Chen et al., 2018)

\subsection{Stochastic Frontier Analysis (SFA) and Stochastic Meta-Frontier (SMF)}

Aigner, Lovell, \& Schmidt (1977) proposed the stochastic frontier production function, which adopts a parameter approach, to estimate the technical efficiency of decision making units (DMUs). Inheriting this idea, a two-stage approach was employed to estimate technical efficiency and the impact of exogenous factors to this efficiency separately (Pitt \& Lee, 1981). Nonetheless, this two-stage leads to serious biased estimations in both stages due to inconsistent assumptions (identical distribution of efficiency effects). Battese and Coelli (1995) introduced a model which allows us to estimate the frontier function as well as technical inefficiency model simultaneously. This model, in fact, not only helps to explore the determinants of efficiency but also accounts for technical change as well as time-varying effect.

The metafrontier, on the other hand, is considered as an envelope of all groups' stochastic frontiers. Battese et al. (2004) suggested a linear programming (LP) method to estimate the parameters of this metafrontier. Nonetheless, the most serious drawback of this approach is that the estimated metafrontier has no statistical meaning due to the fact that it is calculated by the mathematical programming (Huang, et al., 2014). Therefore, they advocate the use of stochastic metafrontier approach, which can not only give relevant statistical inferences but also account for influence of environmental variables on technical gap ratio.

\section{Political Systems and Bank Reforms in China and Vietnam}

\subsection{Political and Electoral Systems in Vietnam and China}

The most conspicuous feature that China and Vietnam share the same is that their political institutions are 
constructed under a single-party (Communist Party) framework. This framework pressures a reality that the party committees at all administrative level sustain the most powerful and pivotal role. The electoral procedures in these two nations are both based on a hierarchical model, in which only the lowest level of the administrative units (named as People's Council in Vietnam and local People's Congress in China) are directly elected while all of the other upper levels are indirectly elected.

In the direct election level, there usually lack publicly posting brief biographies (or even basic information) of the candidates for the voters and very little time for the meetings between deputies and constituents. This has been consequently raised the suspicions about a meaningful connection between candidates and voters in both countries (McCormick, 1998).

Nevertheless, the parliaments themselves appeared to be more dynamic. For example, the Vietnamese National Assembly, in 1998, criticized the government for requesting rice from cities suffered famine (Note 1). In 1997, the Prime Minister's appointment for the Governor of the State Bank of Vietnam was rejected by the National Assembly due to a number of problems in central bank's operation (Note 2). The China's National People's Congress has recently witnessed a common number up to 30 percent of the deputies to vote against an ineligible candidates or legislative proposal (McCormick, 1998). Particularly, in the meeting of the National People's Congress in 1995, two of Li Peng's candidates for government - level office just received very few apathetic approvals.

The parliamentary elections, which are highly associated with political transitions, always pressure a significant transformation for the economy in general and the financial industry particularly. In other word, it can be said that all of governments always try to put their distinction in every corner of the economy. Even though this phenomenon is somewhat more evident in the democratic countries, it is still noticeable in single-party systems like China and Vietnam.

\subsection{Bank Reforms and Performance in China and Vietnam}

The renovation of economy and financial industry in China and Vietnam shares a lot of similar characteristics. The aim of transition from "central-planned economy" to market-oriented economy" pressured their banking industries to exercise various transformations. One of those involved with alignments of the equity structure in order to improve the competitiveness and effectiveness of the industry. In detail, there are three popular trend regarding ownership restructuring, named as "one tier to two tier strategy", "privatization", and "merger and acquisition" (M\&A).

In short, the banking reforms in China and Vietnam are mostly associated with partially denationalizing state-owned banks (SOBs), establishing various joint stock commercial banks (JSCBs), and relaxing foreign investment. With the promulgation of the Law of the People's Republic of China on Commercial Bank (July 1995), three of the "Big Four" reached agreements to take on minority foreign ownership. As in Vietnam, the "equitized strategy" announced in 2006 planned to deduct the government ownership to as much as $51 \%$ by 2010 . By the end of 2009 , majority of SOBs in China and Vietnam had successfully done their IPOs to increase and diversify their equity. On the other hand, the participation of foreign investors in these banking industries are not only limited as joint-venture form or strategic investors but also extensive to the presence of official wholly foreign banks (FBs). By the end of 2013, the total asset of FBs in China dramatically increased to reach RMB 2.56 trillion (compared to RMB 582 billion in 2004 (Note 3)), while the foreign investment in Vietnam financial sector accounted for more than $11 \%$ of the whole industry (Note 4). In addition to the augmentation of FBs, the period of time during 2000s also witnessed the foundation of numerous private banks under variety of forms in China and Vietnam.

These reforms, indeed, has brought a lot of benefits in term of performance for both China and Vietnam banking industry. The popular trend has revealed that China banks perform better and better and reach to a stable status after the financial crisis (e.g., Kumbhakar and Wang, 2007; Yin, et al., 2013). A similar trend also evidenced for Vietnam (Vu and Turnell, 2010; Nguyen, et al., 2016). Nevertheless, the effectiveness of state-owned institutions is somewhat interestingly controversial. For instance, a number of studies argued that China major state-owned banks are the least efficient among the other types, and the participant of foreign investors will increase the performance significantly (Kumbhakar \& Wang, 2007; Berger et al., 2009; Asmild \& Matthews, 2012). Thus, they suggested policy makers to encourage the appearance of foreign factors in China banking system in order to exploit the advantages of advanced technology and operating experiences. On the other hand, few studies (e.g., Zhu et al., 2015) dispute that China state-owned banks are not necessary inferior to the other types of banks and explain this ascension of government-owned banks may be the results of funding injection to deal with non-performing loan and successful listing on stock market thank to government's favor. As for Vietnam, while Stewart et al. (2016) concluded that, non-state owned commercial banks outperform state-owned ones, $\mathrm{Vu}$ and Turnell (2010) could not find the significant difference between those groups of banks. Phan and Daly (2014) argued that government-owned banks 
are even more efficient than private bank in term of cost optimization. However, all of those studies concur on the superior performance of foreign banks and advocated the participation of foreign investors in local banks.

\section{Model Specification and Variable Description}

\subsection{Stochastic Cost Frontier}

Banking is a complex business with multiple inputs/outputs, hence a production function in this situation is feasible (Koetter, et al., 2006). Under the assumption of rational behavior, cost minimization seems to be one of the most crucial issues that a bank has to take into account (Note 5). Therefore, adopting a cost function is apparently a better solution for measuring bank's efficiency.

We adopt a popular intermediation approach (Sealey \& Lindley, 1977) to define the input and output variables for our cost function model. The two output variables are loans $\left(Y_{1}\right)$ and investment $\left(Y_{2}\right)$, which account for almost all of the profit-gaining activities in a bank. As for input variables, we use $X_{1}, X_{2}, X_{3}$, to denote labors, physical assets and borrowed funds, respectively (Altunbas, et al., 2000). Because the data of full-time employee is incomplete for Vietnam and China banks in Bankcope, we choose total assets to replace this data as for labor input (Huang, et al., 2011). We then define price of labor (P1) as the ratio of personnel expenses to total assets; price of capital (P2) as the ratio of non-interest expenses to physical assets; and the ratio of interest expenses to borrowed funds as the price of fund (P3). Finally, the total costs are the summation of those three aforementioned expenses.

Following Berger and de Young (1997), we construct a Cobb-Douglas cost frontier function in trans-log form. Furthermore, we impose linearly homogenous condition in input prices by normalizing total cost and a specific price. This procedure generates a cost function as follows:

$$
\begin{aligned}
\ln \left(\frac{T C_{i t}}{P_{1 i t}}\right)= & \beta_{0}+\beta_{1} \ln \left(\mathrm{Y}_{1 i t}\right)+\beta_{2} \ln \left(\mathrm{Y}_{2 i t}\right)+\beta_{3} \ln \left(\frac{P_{2 i t}}{P_{1 i t}}\right)+\beta_{4} \ln \left(\frac{P_{3 i t}}{P_{1 i t}}\right)+\frac{1}{2} \beta_{11}\left[\ln \left(\mathrm{Y}_{1 i t}\right)\right]^{2}+\frac{1}{2} \beta_{22}\left[\ln \left(\mathrm{Y}_{2 i t}\right)\right]^{2}+\frac{1}{2} \beta_{12} \ln \left(\mathrm{Y}_{1 i t}\right) \ln \left(\mathrm{Y}_{2 i t}\right) \\
& +\frac{1}{2} \beta_{33}\left[\ln \left(\frac{P_{2 i t}}{P_{1 i t}}\right)\right]^{2}+\frac{1}{2} \beta_{44}\left[\ln \left(\frac{P_{3 i t}}{P_{1 i t}}\right)\right]^{2}+\frac{1}{2} \beta_{34} \ln \left(\frac{P_{2 i t}}{P_{1 i t}}\right) \ln \left(\frac{P_{3 i t}}{P_{1 i t}}\right)+\beta_{13} \ln \left(\mathrm{Y}_{1 i t}\right) \ln \left(\frac{P_{2 i t}}{P_{1 i t}}\right)+\beta_{14} \ln \left(\mathrm{Y}_{1 i t}\right) \ln \left(\frac{P_{3 i t}}{P_{i i t}}\right) \\
& +\beta_{23} \ln \left(\mathrm{Y}_{2 i t}\right) \ln \left(\frac{P_{2 i t}}{P_{1 i t}}\right)+\beta_{24} \ln \left(\mathrm{Y}_{2 i t}\right) \ln \left(\frac{P_{3 i t}}{P_{1 i t}}\right)+\mathrm{v}_{i t}+u_{i i} ;
\end{aligned}
$$

where $T C_{i t}, Y_{i t}, P_{i t}$ represent for total costs, outputs and prices of input for $i^{\text {th }}$ bank at time $\mathrm{t} ; \beta$ are unknown parameters need to be estimated; $v_{i t}$ is random error; and $u_{i t}$ is technical inefficiency.

Under Battese and Coelli (1995) model, the random error, $v_{i t}$, is assumed to be independent and identically distributed (i.i.d), $v_{i t} \sim N\left(0, \sigma_{v}^{2}\right)$, and also independently distributed of the technical inefficiency, $u_{i t}$. Similarly, $u_{i t}$ is also assumed to be i.i.d, non-negative, and truncated normal distributed, $u_{i t} \sim N^{+}\left(\mu_{i t}=z_{i t} \delta, \sigma_{u}^{2}\right)$. The mean of technical inefficiency, in detail, can be expressed as:

$$
\mu_{i t}=\delta_{0}+\sum_{k=1}^{8} \delta_{k} z_{k i t}+\varepsilon_{i t}
$$

Where $z_{\text {kit }}$ denotes the $\mathrm{k}^{\text {th }}$ exogenous variable $(k=1$ to 8$)$ associated with technical inefficiency. For the purpose of our study, we choose variables related to ownership structure and some other environmental variables to control for the outcome. The detail of these variables will be described in the next section.

\subsection{Meta-Cost Frontier Function}

There is a fact that firms operating in different countries should have different levels of technology. Therefore, the technical efficiencies, which are assumed to be defined by the stochastic cost frontier, are totally incomparable across countries. Following the SMF approach proposed by Huang et al. (2014), our processes to estimate the meta-cost efficiency for China and Vietnam banking industry can be expressed as following.

In the first step, we estimate the frontier of each group - specific $\mathrm{j}$ using a panel data of $\mathrm{Nj}$ firms in $\mathrm{T}$ periods, i.e.,

$$
\ln Y_{j i t}=\ln f_{t}^{j}\left(X_{j i t}\right)+v_{j i t}-u_{j i t}, \quad i=1,2 \ldots, N_{j} ; t=1,2, \ldots, T
$$

The distribution's assumptions of $v_{j i t}$ and $u_{j i t}$ are the same as in (1) and (2).

Secondly, from the SF estimates of the group - specific frontiers $\hat{f}_{t}^{j}\left(X_{j i t}\right)$ for all $\mathrm{j}=1,2, \ldots, \mathrm{J}$ groups, the stochastic meta-frontier (SMF) can be expressed as:

$$
\ln \hat{f}_{t}^{j}\left(X_{j i t}\right)=\ln f_{t}^{M}\left(X_{j i t}\right)-U_{j i t}^{M}+V_{j i t}^{M}, \forall i, t, j=1,2, \ldots J
$$

Finally, the relation between estimated meta technical efficiency (MTE), estimated technology gap ratio (TGR) and 
estimated firm's conventional technical efficiency is as following

$$
\widehat{M T E}_{i t}^{j}=\widehat{T G R}_{i t}^{j} \times \widehat{T E}_{i t}^{j}
$$

Inasmuch as this metafrontier is based on a stochastic framework, we are able to evaluate not only the TGR, but also its determinants. For instant, one can assume that the TGR $U_{i t k}^{*}$ follows a truncated-normal, i.e., $U_{i t k}^{*} \sim N^{+}\left(\mu^{*}\left(Z_{i t r}\right), \sigma_{u}^{* 2}\left(Z_{i t r}\right)\right)$. In this case, the mean of TGR, $\mu^{*}\left(Z_{i t r}\right)$, which is presented as a function of environmental variables $Z_{i t r}$, reflects the influence of those exogenous factors to the technology level of a group that a firm operates in. In the other hand, the heteroskedastic variance $\sigma_{u}^{* 2}\left(Z_{i t r}\right)$ illustrates the production uncertainty.

\subsection{Data Selection}

Our study focuses on investigating China and Vietnam bank's efficiency for the period of time from 2009 to 2013. The dataset used in this paper can be divided into two main groups.

The first group contains of variables related to frontier function (inputs and outputs) is mostly collected from Bankscope (Bureau van Dijk) - the most popular and comprehensive data souse for banking sector (Note 6). After some filtering, we get the unbalanced panel data which consists of 58 China banks and 36 Vietnam banks. This sample accounts for more than $85 \%$ of total asset for banking industries in both countries. To make the data consistent across two countries, we convert all the currency into USD and deflate all values using 1995 as based year.

The second group of variables (ownership structure and other control variables), unfortunately, is unavailable in Bankscope. Therefore, we manually download annual reports from each bank's website and collect variables systematically. For some China banks, this data also can be obtained through TEJ (Taiwan Economic Journal). For the purpose of our research, we collect information about the percentage of government, foreign, and domestic ownership.

The detail definitions and descriptive statistics for all variables are shown in Table 1.

Table 1. Input price and output variables for cost function

\begin{tabular}{|c|c|c|c|c|c|c|c|c|c|c|}
\hline \multirow{2}{*}{ Variable } & & \multirow{2}{*}{ Definition } & \multicolumn{4}{|c|}{ China } & \multicolumn{4}{|c|}{ Vietnam } \\
\hline & & & Mean & Min & Max & S.D & Mean & Min & Max & S.D \\
\hline \multirow{3}{*}{ Input } & $\begin{array}{l}\text { Price of } \\
\text { labor }\left(P_{1}\right)\end{array}$ & $\begin{array}{l}\text { Ratio of } \\
\text { personnel } \\
\text { expenses to } \\
\text { total asset }\end{array}$ & .006083 & .000512 & .021334 & .0028839 & .007744 & .000556 & .027795 & .003454 \\
\hline & $\begin{array}{l}\text { Price of } \\
\text { capital }\left(\mathrm{P}_{2}\right)\end{array}$ & $\begin{array}{l}\text { Ratio of } \\
\text { non-interest } \\
\text { expenses to } \\
\text { fixed assets }\end{array}$ & 1.82878 & .107429 & 24.3368 & 2.847066 & 2.38996 & $2.2 \mathrm{e}-15$ & 24.6588 & 3.80217 \\
\hline & $\begin{array}{l}\text { Price of } \\
\text { fund }\left(\mathrm{P}_{3}\right)\end{array}$ & $\begin{array}{l}\text { Ratio of } \\
\text { interest } \\
\text { expenses to } \\
\text { total funding. }\end{array}$ & .019472 & .003054 & .044701 & .007201 & .066826 & .001978 & .138851 & .027443 \\
\hline \multirow{2}{*}{ Output } & $\begin{array}{l}\text { Total Loans } \\
\left(Y_{1)}\right.\end{array}$ & $\begin{array}{l}\text { Net loans } \\
\text { (from } \\
\text { Bankscope) }\end{array}$ & $1.79 * 10^{8}$ & 104,442 & $1.57 * 10^{9}$ & $3.25^{*} 10^{8}$ & $3,167,247$ & 7,136 & $2.6^{*} 10^{7}$ & 516,736 \\
\hline & $\begin{array}{l}\text { Investment } \\
\left(\mathrm{Y}_{2}\right)\end{array}$ & $\begin{array}{l}\text { Other earning } \\
\text { assets (from } \\
\text { Bankscope) }\end{array}$ & $1.62 * 10^{8}$ & 367,128 & $1.40^{*} 10^{9}$ & $2.88^{*} 10^{8}$ & $1,807,570$ & 3,935 & $8,089,651$ & $1,950,931$ \\
\hline \multicolumn{2}{|c|}{ Total cost (TC) } & $\begin{array}{l}\text { Personnel } \\
\text { expenses + } \\
\text { non-interest } \\
\text { expenses + } \\
\text { interest } \\
\text { expenses }\end{array}$ & $1.01^{*} 10^{7}$ & 33,523 & $9.00^{*} 10^{7}$ & $1.70^{*} 10^{7}$ & 434,211 & 1,541 & $3,435,525$ & 629,759 \\
\hline
\end{tabular}

Note: The units of all variables, except the ratios, are in thousand U.S dollars.

\section{Empirical Results Analysis}

\subsection{Result of Stochastic Frontier Cost Functions}

The estimation of the cost frontier is shown in Table 2. Note that in the Battese and Coelli (1995) model, the cost frontier and inefficiency model are simultaneously estimated. In the first model, we characterize ownerships by using two dummy variables which represent for SOs and FBs. In the model 2, our consideration focuses on two main 
variables, namely the percentage of government's shares and foreigner's shares. Before going on to the detail analysis, we should start by describing some findings from the stochastic cost frontier function.

Table 2. Empirical result of stochastic cost frontiers

\begin{tabular}{|c|c|c|c|c|c|c|c|c|c|c|c|c|}
\hline & \multicolumn{3}{|c|}{ China (Model 1) } & \multicolumn{3}{|c|}{ China (Model 2) } & \multicolumn{3}{|c|}{ Vietham (Model 1) } & \multicolumn{3}{|c|}{ Vietnam (Model 2) } \\
\hline & Coefficient & S.E & t-ratio & Coefficient & S.E & t-ratio & Coefficient & S.E & t-ratio & Coefficient & S.E & t-ratio \\
\hline Constant & $1.7532^{*}$ & 1.0217 & 1.7160 & $2.8861^{* * *}$ & 1.0035 & 2.8760 & $-12.208^{* * *}$ & 1.2740 & $\begin{array}{l}-9.5824 \\
\end{array}$ & $-9.9701^{* * *}$ & 1.0626 & -9.3823 \\
\hline $\ln \mathrm{Y}_{1}$ & 0.3732 & 0.2959 & 1.2614 & 0.1906 & 0.2270 & 0.8395 & $2.6565 * * *$ & 0.5487 & 4.8415 & $3.0071^{* * *}$ & 0.7095 & 4.2385 \\
\hline $\ln Y_{2}$ & $0.6599 * * *$ & 0.2293 & 2.8779 & $0.7529 * * *$ & 0.1891 & 3.9824 & $1.5019 * *$ & 0.7124 & 2.1082 & 0.0056 & 0.8555 & 0.0065 \\
\hline $\ln \left(\mathbb{P}_{2} / \mathbb{P}_{1}\right)$ & $-0.2379^{* * *}$ & 0.1039 & -2.2906 & $-0.3759 * * *$ & 0.1230 & -3.0549 & -0.0758 & 0.5441 & -0.1393 & 0.7430 & 0.5953 & 1.2482 \\
\hline $\ln \left(\mathbb{P}_{3} / \mathbb{P}_{1}\right)$ & 0.3821 & 0.3442 & 1.1103 & $0.3610^{*}$ & 0.2108 & 1.7123 & $-1.8989 * * *$ & 0.5968 & -3.1815 & $-2.2127^{* *}$ & 0.9701 & -2.2808 \\
\hline$(1 / 2)\left(\ln Y_{1}\right)^{2}$ & $0.3528 * * *$ & 0.0260 & 13.5634 & $0.3456^{* * *}$ & 0.0225 & 15.3651 & $0.0224^{* *}$ & 0.0086 & 2.6100 & $0.0478^{* * *}$ & 0.0091 & 5.2540 \\
\hline$(\%)\left(\ln \mathrm{Y}_{2}\right)^{2}$ & $0.3145^{* * *}$ & 0.0282 & 11.1527 & $0.2953^{* * *}$ & 0.0307 & 9.6274 & $0.1880^{* * *}$ & 0.0339 & 5.5480 & $0.2161^{* * *}$ & 0.0448 & 4.8187 \\
\hline$(1 / 2)\left(\ln Y_{1}\right)\left(\ln Y_{2}\right)$ & $-0.6708^{* * *}$ & 0.0493 & . 13.5961 & $-0.6411^{* * *}$ & 0.0519 & -12.3554 & $-0.4545^{* * *}$ & 0.0520 & -8.7463 & $-0.3684 * * *$ & 0.0549 & -6.7051 \\
\hline$(\% / 2)\left[\ln \left(\mathbb{P}_{2}, P_{1}\right)\right]^{2}$ & 0.0241 & 0.0149 & 1.6217 & $0.0316^{* * *}$ & 0.0105 & 3.0059 & $0.1294^{* * *}$ & 0.0410 & 3.1567 & 0.0134 & 0.0753 & 0.1774 \\
\hline$(\%)\left[\ln \left(\mathbb{P}_{3}, \mathbb{P}_{1}\right)\right]^{2}$ & $0.1552^{* * *}$ & 0.0203 & 7.6394 & $0.1557 * * *$ & 0.0227 & 6.8655 & $0.3769^{* * *}$ & 0.0848 & 4.4436 & $0.2962 * * *$ & 0.1000 & 2.9632 \\
\hline$(\%) \ln \left(\mathbb{P}_{2} \mathbb{P}_{2}\right) \ln \left(\mathbb{P}_{3}, \mathbb{P}_{1}\right.$ & -0.0108 & 0.0523 & -0.2064 & $-0.0066^{*}$ & 0.0359 & -0.1844 & 0.0109 & 0.1502 & 0.0729 & 0.1744 & 0.1638 & 1.0647 \\
\hline $\ln Y_{1} * \ln \left(P_{2} / \mathbb{P}_{1}\right)$ & -0.0096 & 0.0211 & -0.4536 & 0.0030 & 0.0204 & 0.1480 & -0.0474 & 0.0307 & -1.5436 & $-0.1262^{*}$ & 0.0651 & -1.9394 \\
\hline $\ln Y_{1} * \ln \left(P_{3} / P_{1}\right)$ & $-0.0672^{* * *}$ & 0.0195 & -3.4477 & $-0.0749 * * *$ & 0.0135 & -5.5651 & 0.1098 & 0.0760 & 1.4439 & 0.0564 & 0.0904 & 0.6240 \\
\hline $\ln \mathrm{Y}_{2} * \ln \left(\mathrm{P}_{2} / \mathbb{P}_{1}\right)$ & 0.0174 & 0.0178 & 0.9762 & 0.0106 & 0.0176 & 0.6050 & -0.0253 & 0.0317 & -0.7971 & 0.0285 & 0.0730 & 0.3908 \\
\hline $\ln Y_{2} * \ln \left(P_{3} / \mathbb{P}_{1}\right)$ & $0.0722^{* * *}$ & 0.0140 & 5.1545 & $0.0806^{* * *}$ & 0.0115 & 7.0256 & -0.0732 & 0.0922 & -0.7944 & -0.0062 & 0.1062 & -0.0588 \\
\hline$\sigma^{2}$ & $0.1319^{* * *}$ & 0.0025 & 5.3386 & $0.0135^{* * *}$ & 0.0015 & 9.0394 & $0.0619^{* * *}$ & 0.0079 & 7.6607 & $0.0897 * * *$ & 0.0150 & 5.9633 \\
\hline$r$ & $0.9945^{* * *}$ & 0.0110 & 90.091 & $0.9993 * * *$ & 0.0042 & 235.46 & $0.6727^{* * *}$ & 0.0438 & 15.357 & $0.7253^{* * *}$ & 0.0702 & 10.335 \\
\hline LR-test & $103.58738^{* * *}$ & & & $113.60855^{* * *}$ & & & $96.048977 * *$ & & & $36.659136^{*}$ & & \\
\hline
\end{tabular}

Note: *** represents significance at $1 \%$ level; ** represents significance at $5 \%$ level; * represents significance at $10 \%$ level; Model 1 uses dummy variables to represents for state-owned banks and foreign banks; Model 2 uses percentage of state-holder and foreign-holder

First of all, Table 2 indicates that more than a half of the estimated parameters (outputs, input prices and the interaction terms) are statistically significant at least at $10 \%$ level. Furthermore, since $\sigma^{2}\left(=\sigma_{u}^{2}+\sigma_{v}^{2}\right)$ and $\gamma\left(=\sigma_{u}^{2} / \sigma^{2}\right)$ in both models are all statistically significant at $1 \%$, it is confirmed that inefficiency exists in the cost frontier of both China and Vietnam banks. The value of $\gamma$ s indicates that the variation of the noise terms is mostly due to the variation of technical inefficiency. These conclusions are in line with the assumptions of Battese and Coelli (1995) model.

The likelihood ratio test (LR-test) is employed for verifying the goodness of fit for the frontier function. With the exception of Vietnam in model 2 (significant at 10\% level), all of the other three LR statistics are significant at $1 \%$ level. This indicates that the proposed stochastic frontiers are appropriate for both countries in both models.

Finally, the results of cost frontier in both China and Vietnam are consistent with the microeconomics theory. That is, cost function is satisfied the non-decreasing in input prices, and concavity conditions (Note 7). From all of these points, it can be verified that the estimated cost frontier functions, in this case, are well represented for the real operating cost in banking industry of both countries.

\subsection{Ownership Structure and Technical Cost Efficiency}

In addition to four main explanatory variables reflecting bank's ownership, we also include some control variables to reduce the unexplained part of the cost inefficiency (equation 2). These variables account for bank's basic characteristics (e.g. bank size, number of branches), the profitability factors (e.g. ROE, ROA), and the risk factors (credit risk, market risk, operational risk, or liquidity risk). Finally, in order to avoid the multicollinearity effect (Note 8 ), it is necessary to conduct a correlation matrix test. This step deducts our amount of variables from 15 to 8 for each model. The detailed definitions of all environmental variables are shown in table 3.

Table 3. Exogenous variables in efficiency models

\begin{tabular}{ll}
\hline Variable & Definition \\
SO & A dummy variable equals 1 if a bank is state-owned bank and 0 otherwise. \\
FB & A dummy variable equals 1 if a bank is foreign bank and 0 otherwise. \\
$\%$ of state ownership & Percentage of stake held by government directly and indirectly. \\
\hline
\end{tabular}




\begin{tabular}{ll}
\hline \% of state ownership & Percentage of stake held by foreigner (instruction or individual) \\
Bank Size & Nature logarithm of bank's total asset \\
Capital Adequacy Ratio & Percentage of bank's risk weighted credit exposures \\
Non-performing Loan & Loans that are not paid by schedule for at least 90 days \\
Age & How long a bank had been established \\
Age squared & Square of age \\
Number of branches & Total amount of bank's branches in domestic region.
\end{tabular}

The estimation of inefficiency models (model 2) is shown in Table 4. Panel A illustrates a significantly positive relation between SOBs and cost inefficiency for China banks. This supports the hypothesis that state-owned banks are less efficient than domestic commercial banks. In detail, the coefficient of "SO variable" suggests that with the ceteris paribus assumption, the cost efficiency of China SOBs, on average, is 0.16 point less than those of domestic commercial banks (Note 9). Furthermore, the coefficient of percentage of government ownership (Panel B) reconfirms that a decrease of 0.27 cost efficiency point will be generated with the increase in participation of government by $1 \%$. Our finding is in line Yin et al. (2013). This phenomenon can be explained by the inefficiency of the Big Four in China. This group, which accounts for a huge proportion of all SOBs, is always considered as the least efficiency compared to the others (Berger, et al., 2009). One can infer that those banks act as the policy regulators rather than chasing for profit purpose, and therefore, lack of motivation to increase the technical efficiency. The other may criticize the main reason of this inefficiency is because of the high portion of non-performing loans as well as the bad operating performance. This result suggests a need for ownership reforming in the majority state sector, however, policy makers still have to take into account the role of those banks in the whole industry.

Table 4. Estimation of inefficiency models

Panel A

\begin{tabular}{|c|c|c|c|c|c|c|}
\hline & \multicolumn{3}{|l|}{ China } & \multicolumn{3}{|l|}{ Vietnam } \\
\hline & Coefficient & S.E & t-ratio & Coefficient & S.E & t-ratio \\
\hline Constant & $0.7926^{* * *}$ & 0.1633 & 4.8539 & $-9.4956 * * *$ & 1.0284 & -9.2335 \\
\hline SO & $0.1556 * * *$ & 0.0541 & 2.8758 & -0.0644 & 0.1409 & -0.4566 \\
\hline FB & $-0.1446 * * *$ & 0.0409 & -3.5352 & $-1.0146 * * *$ & 0.1366 & -7.4279 \\
\hline Bank size & $-0.0467 * * *$ & 0.0122 & -3.8183 & $0.7916^{* * *}$ & 0.0746 & 10.6115 \\
\hline $\begin{array}{l}\text { Capital Adequacy } \\
\text { Ratio }\end{array}$ & $-0.0807^{*}$ & 0.0448 & -1.8036 & -0.1900 & 0.5995 & -0.3170 \\
\hline $\begin{array}{l}\text { Non-Performing } \\
\text { Loan }\end{array}$ & $1.0950 * * *$ & 0.3552 & 3.0829 & $2.1053^{*}$ & 1.2687 & 1.6593 \\
\hline Age & $-0.0089 * *$ & 0.0042 & -2.1003 & $-0.0270 * *$ & 0.0128 & -2.1089 \\
\hline Age square & $0.00008 * *$ & 0.000036 & 2.1459 & $0.00048 * *$ & 0.0002 & 2.3720 \\
\hline $\begin{array}{l}\text { Number } \\
\text { Branches }\end{array}$ & 0.0000005 & 0.000008 & 0.6389 & $-0.000037^{*}$ & 0.00002 & -1.9768 \\
\hline \multicolumn{7}{|l|}{ Panel B } \\
\hline & \multicolumn{3}{|l|}{ China } & \multicolumn{3}{|l|}{ Vietnam } \\
\hline & Coefficient & S.E & t-ratio & Coefficient & S.E & t-ratio \\
\hline Constant & $0.8826 * * *$ & 0.1350 & 6.5383 & -1.4414 & 2.7145 & -0.5310 \\
\hline $\begin{array}{l}\% \quad \text { of } \quad \text { state } \\
\text { ownership }\end{array}$ & $0.2744 * * *$ & 0.0602 & 4.5563 & $-0.6094 * * *$ & 0.1676 & -3.6353 \\
\hline $\begin{array}{ll}\% & \text { foreign } \\
\text { ownership } & \end{array}$ & $-0.2417 * * *$ & 0.0462 & -5.2367 & $-0.8493 * * *$ & 0.2189 & -3.8802 \\
\hline Bank size & $-0.0454 * * *$ & 0.0112 & -4.0682 & 0.1683 & 0.1564 & 1.0758 \\
\hline
\end{tabular}




\begin{tabular}{llllllc} 
Capital Adequacy & $-0.0515^{* * *}$ & 0.0127 & -4.0476 & -0.4587 & 1.4209 & -0.3228 \\
$\begin{array}{l}\text { Ratio } \\
\text { Non-Performing }\end{array}$ & $1.0657 * * *$ & 0.3124 & 3.4115 & 3.4997 & 3.8929 & 0.8990 \\
$\begin{array}{l}\text { Loan } \\
\text { Age }\end{array}$ & $-0.0118^{* * *}$ & 0.0038 & -3.0849 & $-0.0412^{* * *}$ & 0.0152 & -2.7128 \\
$\begin{array}{l}\text { Age square } \\
\begin{array}{l}\text { Number } \\
\text { Branches }\end{array}\end{array}$ & $0.0001 * * *$ & 0.00003 & 3.3410 & $0.0007 * *$ & 0.0003 & 2.4999 \\
\hline
\end{tabular}

Note: The estimation in Panel $A$ and Panel B represents for inefficiency model 1 and model 2 , respectively; *** represents significance at $1 \%$ level; ** represents significance at $5 \%$ level; * represents significance at $10 \%$ level

As for Vietnam banking system, the negative relation between SOBs and inefficiency suggests that those banks outperform private domestic banks. However, this relation seems to be weak and not really clear because its coefficient is just statistically significant at about $15 \%$ level. This result is consistent with other researches for Vietnam banking sector (e.g., Vu and Turnell, 2010) which also did not find a strong evidence for the difference between SOBs and JCBs in term of performance. This can be explained by the intense competition in Vietnam banking sector that forces SOBs to reform expenditure structure in order to optimize inputs. On the other hand, these banks have more experiences to deal with the difficulties of post-financial crisis. More interestingly, the result in Panel B confirms that an increase in the proportion of government's share will significantly decrease cost inefficiency. This is a common trend for emerging markets that their governments still play a very important role in financial sector and banks (Ariff and Can, 2008).

As for foreign banks, since both Chinese and Vietnamese market regulations are strict for the entry of foreign capital, it is found that a small amount of this investment can eventually increase bank's efficiency (Berger et al., 2009; Fries and Taxi, 2005). Our result indicates a similar trend across Vietnam and China banking industry that is in relative with private domestic banks, foreign banks in both countries are apparently better in term of cost efficiency. Therefore, transitively, this group can be considered as the best performer among the others. Some scholars may argue that this inferiority of local banks is because of the late entrance of foreign banks, and therefore, less of bad outputs (for instant, non-performing loans). However, the significantly positive sign of foreign shareholders in panel B declares that the appearance of outside-border investment in Vietnam and China banking industry assist to improve systems' performance. This finding suggests the transition economies to exploit the advantages of experience and technology from foreign investment in order to increase the performance.

Regarding the control variables, we find the consistent results in both inefficiency models for both Vietnam and China banking industry. For instance, in China, bank size has positively significant impact on the cost efficiency, while in Vietnam, a reverse phenomenon is exposed. After the WTO accession of China, when a bank expands its size to a certain level, efficiency is gained, and economy of scale is also recognized (Yin, et al., 2013). However, in Vietnam, this trend still seems to be ambiguous. This reflects a fact that Chinese banks better exploited the comparative advantage of scale than Vietnamese counterparts. Nevertheless, we find that in Vietnam, the more branches a bank have, the better it performs in terms of cost efficiency. It suggests that Vietnamese banks should distribute their capital to open small agencies rather than concentrate on expanding their headquarters. The rest of the variables' effect is quite similar and in line with other investigations across Vietnam and China. Non-performing loan, which represents credit risk, has the bad impact on cost efficiency as we expected (Sun \& Chang, 2011). As a proxy of risk management (Chortareas, et al., 2012), our result supports that capital adequacy ratio (CAR) has a positive impact on cost efficiency. Finally, in both countries, we find that the operating experience of bank (denoted by its age) can assist to improve the performance.

\subsection{The Role of Politics}

Levy-Yeyati et al. (2004) notices the difficulty when the cross-country data is employed to explore the political motivation behind the behavior of state-owned banks. However, as for bank-level data, many studies find evidences about the manipulation of "behind the scenes" ascendency in the lending decisions of state-owned banks (Dinç, 2005). Inheriting the spirit of Micco et al. (2007), we take into account the presence of politic factors while evaluating the relation between ownership structure and bank's efficiency. The inefficiency model, therefore, can be set as following.

$$
\mu_{i t}=\delta_{0}+S O_{i t}\left(\alpha_{1}+\alpha_{2} E L E C T_{t}+\alpha_{3} G R O W T H_{t}\right)+F B_{i t}\left(\theta_{1}+\theta_{2} G R \quad T H_{t}\right)+\sum_{k=6}^{11} \delta_{k} z_{k i t}+\varepsilon_{i t} ;
$$


In this set up, ELECT $T_{t}$ is a dummy variable that will take the value 1 if in year $\mathrm{t}$ the country has an election and 0 otherwise (Note10). Thus, our main interest coefficient is $\alpha_{3}$ which differentiates the effect of elections on performance of state-owned banks. Our hypothesis is based on the political view in which there should be a positive value of $\alpha_{2}$ (elections increase state-owned banks' inefficiency). Additionally, the political business cycle theory suggests that because there may exist a correlation between business cycles and electoral cycles, the reactions of different type of banks seem to be very diverse. Hence, we use another variable $G R O W T H_{t}$ (real GDP growth in year t) to control for this correlation by interacting it with bank's ownership.

The result of inefficiency models is reported in Table 5. The effect of political factors can be described through the three main variables SO*ELECT, SO*GROW, and $\mathrm{FB} *$ GROW, which illustrate the differences of cost inefficiency during the election years and the economic expansion period. Our result, as predicted by political view, points out that in comparison with domestic private banks, SOBs in both countries tend to be more inefficient in election year but better perform during period of economic expansion. As emerging markets, this finding is in line with Micco et al. (2007), Dinç (2005) and Jackowicz et al. (2013). However, the magnitude of the coefficient $\alpha_{2} s$ in two models illustrates a considerable difference in the effects of election in China and Vietnam toward SOB's efficiency. That is, in the election year, China SOBs' inefficiency tends to be increased by 0.6 point, which is tenfold greater than the case of Vietnam (0.06 point). Conversely, SOBs in both countries significantly benefit from economic growth (the signs of $\alpha_{3} s$ in both models are negavetive and statistically significant at 5\%). Finally, while we find evidence against FBs's efficiency during the period of economic expansion in Vietnam, the counterparts in China tend to be benefited from this effect.

\subsection{Empirical Result of Meta-Cost Frontier}

Before estimating the meta-frontier function for Vietnam and China banks, we briefly discuss about their conventional efficiency scores during the period of time from 2009 to 2013. Figure 1 shows that China banks are significantly more efficient than Vietnam banks. In detail, the efficiency score of China fluctuates around 1 and 1.5; while for Vietnam, it is always greater than 3 (Note 11).

Table 5. Estimation of inefficiency models with the political factors

\begin{tabular}{|c|c|c|}
\hline \multirow{2}{*}{ Parameters } & \multicolumn{2}{|c|}{ Dependent variable: mean of inefficiency } \\
\hline & China & Vietnam \\
\hline \multirow{2}{*}{ Constant } & $0.7305 * * *$ & $-1.3058 * *$ \\
\hline & $(0.1174)$ & $(0.6395)$ \\
\hline \multirow{2}{*}{ SO } & $0.1054 * * *$ & -0.5975 \\
\hline & $(0.0893)$ & $(0.8646)$ \\
\hline \multirow{2}{*}{ FB } & $-0.9163 * * *$ & $-0.3753 * * *$ \\
\hline & $(0.1559)$ & $(0.1208)$ \\
\hline \multirow{2}{*}{ SO*ELECT } & $0.6416 * * *$ & $0.0579 * *$ \\
\hline & $(0.0210)$ & $(0.0232)$ \\
\hline \multirow{2}{*}{$\mathrm{SO} * \mathrm{GROW}$} & $-0.6577 * * *$ & $-0.3439 * *$ \\
\hline & $(0.0941)$ & $(0.1742)$ \\
\hline \multirow{2}{*}{$\mathrm{FB} * \mathrm{GROW}$} & $-0.8433 * * *$ & $0.4620 * *$ \\
\hline & $(0.1669)$ & $(0.2026)$ \\
\hline \multirow{2}{*}{ Bank size } & $-0.0433 * * *$ & $0.2269 * * *$ \\
\hline & $(0.0093)$ & $(0.0446)$ \\
\hline \multirow{2}{*}{ Capital Adequacy Ratio } & $-0.0684 * * *$ & $-0.1321 * * *$ \\
\hline & $(0.0087)$ & $(0.0574)$ \\
\hline \multirow{2}{*}{ Non-Performing Loan } & $0.4550 * *$ & $0.4979 * * *$ \\
\hline & $(0.2256)$ & $(0.1084)$ \\
\hline \multirow{2}{*}{ Age } & $-0.0062 *$ & $0.0739 * * *$ \\
\hline & $(0.0035)$ & $(0.0216)$ \\
\hline Age Squared & $0.0053 * *$ & $0.0009 * * *$ \\
\hline
\end{tabular}




$\begin{array}{lll} & 0.0020^{* *} & -0.0013 * * * \\ \text { Number of Branches } & (0.0009) & (0.0003)\end{array}$

Note: The estimation in Panel $A$ and Panel B represents for inefficiency model 1 and model 2, respectively; *** represents significance at $1 \%$ level; ** represents significance at $5 \%$ level; * represents significance at $10 \%$ level; the values in parentheses are t-ratios of estimated coefficients

The above analysis points out that there is a big difference between the banking system of China and Vietnam, therefore using the conventional cost frontier is not favorable in order to compare their performances. Statistically, we apply the LR-test to verify whether there is a significant difference between those two cost frontiers. Only if we can reject the null hypothesis of LR-test, applying the meta-frontier approach is appropriate. The $L R=-2\left\{\ln \left[L\left(H_{0}\right)\right]-\ln \left[L\left(H_{1}\right)\right]\right\}$, in which $\ln \left[L\left(H_{0}\right)\right]$ is the log likelihood function for all sample of the two groups and $\ln \left[L\left(H_{1}\right)\right]$ is the summation of two individual log likelihood functions estimated for each country (Note 12). In this case, the value of LR-statistic is 659.862 , which is much greater than the critical value at even $1 \%$ level $\left(X_{0.01}^{2}(15)=30.578\right)$. This result justifies the use of meta-cost frontier for the comparison of China and Vietnam banking industry's performance.

Table 6. Empirical results of Meta-Cost Frontiers

\begin{tabular}{|c|c|c|c|c|c|c|c|}
\hline \multirow{3}{*}{ Variables } & \multicolumn{5}{|c|}{$\begin{array}{l}\text { Stochastic Approach } \\
\text { (Huang et al., 2014) }\end{array}$} & \multicolumn{2}{|c|}{$\begin{array}{l}\text { Linear Programing Approach } \\
\text { (Bates, 2004) }\end{array}$} \\
\hline & \multicolumn{2}{|c|}{ Meta Cost Frontier } & \multicolumn{3}{|l|}{ Inefficiency Model } & \multicolumn{2}{|c|}{ Meta Cost Frontier } \\
\hline & Coefficient & S.E & $Z$ variables & Coefficient & S.E & Coefficient & S.E \\
\hline Constant & $-11.381^{* * *}$ & 1.240 & Constant & $5.449 * * *$ & 1.265 & -7.130 & 5.293 \\
\hline $\ln Y_{1}$ & $3.483^{* * *}$ & 0.142 & $\%$ of state ownership & $3.114^{* * *}$ & 0.484 & $2.839^{* * *}$ & 0.628 \\
\hline $\ln Y_{2}$ & $-1.429^{* * *}$ & 0.129 & $\%$ of foreign ownership & $-1.060^{* * *}$ & 0.407 & $-1.097^{* *}$ & 0.551 \\
\hline$(1 / 2)\left(\ln Y_{1}\right)^{2}$ & $0.539 * * *$ & 0.158 & Non-performing Loan & -0.379 & 1.508 & 0.045 & 0.048 \\
\hline$(1 / 2)\left(\ln Y_{2}\right)^{2}$ & $0.253^{* * *}$ & 0.012 & Age & $0.047^{* * *}$ & 0.008 & $0.192^{* * *}$ & 0.053 \\
\hline$(2 / 2)\left(\ln Y_{1}\right)\left(\ln Y_{2}\right)$ & $-0.348^{* * *}$ & 0.015 & Age Squared & $-0.0005^{* * *}$ & 0.00007 & $-0.269^{* * *}$ & 0.086 \\
\hline$(1 / 2)\left[\ln \left(\mathrm{P}_{2} / \mathrm{P}_{1}\right)\right]^{2}$ & $-0.049^{* * *}$ & 0.014 & Number of Branches & $-0.0001^{* * *}$ & 0.00001 & -0.039 & 0.034 \\
\hline$(7 / 2)\left[\ln \left(P_{3} / P_{1}\right)\right]^{2}$ & -0.008 & 0.012 & & & & $-0.077^{* * *}$ & 0.019 \\
\hline $\ln \mathrm{Y}_{2} * \ln \left(\mathrm{P}_{3} / \mathrm{P}_{1}\right)$ & $0.046^{* * *}$ & 0.011 & & & & $0.028^{*}$ & 0.017 \\
\hline$\sigma^{2}$ & $0.487^{* * *}$ & 0.079 & & & & & \\
\hline$\gamma$ & $0.986^{* * *}$ & 0.003 & & & & & \\
\hline
\end{tabular}

Note: (1) The standard errors of LP approach are obtained from bootstrapping

(2) The estimation in Panel $A$ and Panel B represents for inefficiency model 1 and model 2, respectively; *** represents significance at $1 \%$ level; ** represents significance at $5 \%$ level; * represents significance at $10 \%$ level

Following the method of Battese (2004) and Huang et al. (2014), we estimate two the meta-cost frontiers to compare the cost efficiency of China and Vietnam banking industry. As reported in Table 6, most of the parameters of the meta-frontier estimated by stochastic approach are statistically significant at $1 \%$ while the standard errors (generated from bootstrapping) in LP approach are not statistically meaningful. Furthermore, another advantage of stochastic approach is that it is able not only to purge the random shocks from inefficiency (reflected by $\sigma^{2}$ and $\gamma$ ), but also to take into account of environmental impacts. 


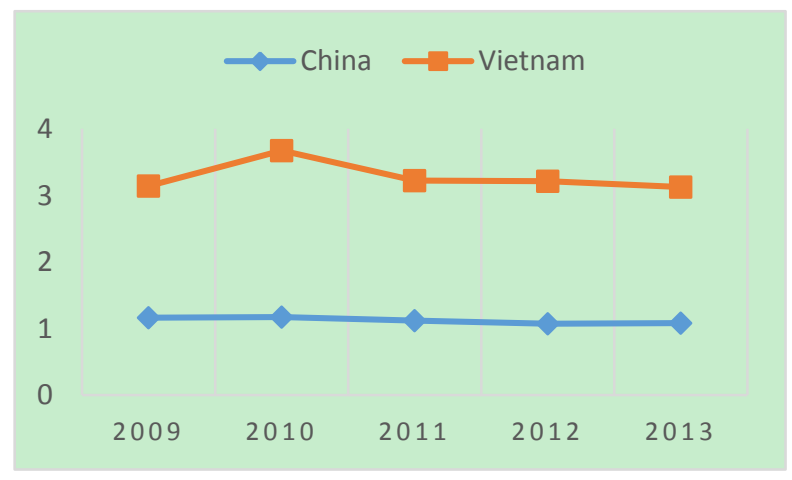

Figure 1. Average conventional efficiency scores

We first analyze the result of cost gap ratio (CGR), which is defined as the gap between the meta-cost frontier and group-specific frontier. The means of CGR of China and Vietnam banking industry are 0.913 and 0.843 as resulted by SMF approach (Huang et al., 2014), respectively. This result is relatively greater than one of LP met frontier (Battese et al., 2004). This reveals a fact that the technology in China banking system is, on average, closer to the best available frontier than the Vietnam counterpart. Additionally, the noticeable fluctuation of CGRs in Vietnam banking compared to China one disclose that banks operating in Vietnam face with more dramatic changes in technology than in China.

Figure 2 and Figure 3 illustrate the meta-cost efficiency (MCE) of China and Vietnam banks by Battese et al. (2004) and Huang et al. (2014). In general, both banking industries appear to be not really efficient (approximately 0.7 and 0.6 as in China and Vietnam, respectively). Similar to the trend of CGR, China banking's efficiency always maintain at a higher level than one of Vietnam. However, the gap is gradually narrowed down for the last three years thanks to the significant improvement in information and technology in Vietnam banking system in recent years.

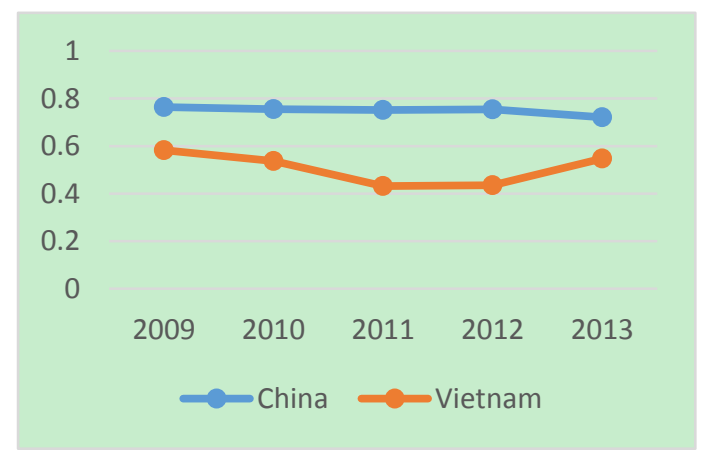

Figure 2. Meta-efficiency by Battese et al. (2004)

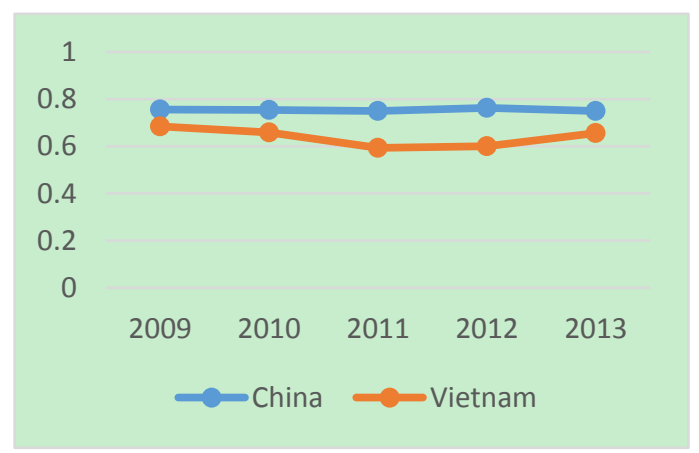

Figure 3. Meta-efficiency by Huang et al. (2014)

As in line with Huang et al. (2014), our result supports that using linear programming method tends to underestimate the CGR and MCE (all of scores generated by Battese et al., 2004 are no greater than those of Huang et al., 2014). This can possibly be explained by the fact that while the linear programming method is confounded with random shocks and its inability to linking with environmental differences, the SMF method is able to purge the random shocks from inefficiency, as well as to take into account of environmental impacts.

\section{Conclusion}

Measuring performance of banking industry in emerging market under the impact of environmental factors had attracted the interest of scholars. There are few studies examine the impact of ownership structure toward bank's performance under the political consideration. However, most of them do not concentrate on evaluating "real performance" but, instead, atop some traditional proxy variables (Micco et al., 2007; Hung et al., 2017; Chen et al., 2018). This paper not only documents the "real performance" (cost efficiency) but also uncover the impact of ownership structure-politics nexus to this performance for China and Vietnam banking industry. 
This study contributes to the literature in practical sense. First, it suggests that the role of government in monitoring financial institutions is undeniable, though, policy makers in both countries need to seriously concern about the performance of banks in public sector. Second, our result advocates the participation of foreign investors in the both China and Vietnam banking market. Especially, Vietnamese domestic banks were benefited from the high level technology and management experience from oversea capital flow during the period of time from 2009 to 2013. Third, we find evidence that political factors have a noticeable influence to cost efficiency of SOBs in the two industries. Particularly, due to the difference in the role of government, the election in China tends to drive down the performance of SOBs more significantly than in the case of Vietnam.

Finally, the paper supports that China banking industry outperforms Vietnam counterpart in term of cost gap ratio and meta-cost efficiency. However, there is an increased trend in Vietnam banks' performance that narrow down the gap of this difference.

However, there still exist limitations in our research that may be extended in future investigations. Due to the restraint of data, we could not deeply explore the real motivation behind the effect of political factors to bank's efficiency, especially, under communist systems.

\section{References}

Aigner, D., Lovell, C., \& Schmidt, P. (1977). Formulation and Estimation of Stochastic Frontier Production Functions. Journal of Econometrics, 6, 21-37. https://doi.org/10.1016/0304-4076(77)90052-5

Altunbas, Y., Liu, M.-H., Molyneux, P., \& Seth, R. (2000). Efficiency and Risk in Japanese Banking. Journal of Banking \& Finance, 24, 1605-1628. https://doi.org/10.1016/S0378-4266(99)00095-3

Andrianova, S., Demetriades, P., \& Shortland, A. (2012). Government Ownership of Banks, Institutions and Economic Growth. Economica, 79, 449-469. https://doi.org/10.1111/j.1468-0335.2011.00904.x

Ariff, M., \& Can, L. (2008). Cost and Profit Efficiency of Chinese Banks: A Non-parametric Analysis. China Economic Review, 19, 260-273. https://doi.org/10.1016/j.chieco.2007.04.001

Asmild, M., \& Matthews, K. (2012). Multi-directional Efficiency Analysis of Efficiency Patterns in Chinese Banks 1997-2008. European Journal of Operational Research, 219(2), 434-441. https://doi.org/10.1016/j.ejor.2012.01.001

Battese, G. E., \& Coelli, T. J. (1995). A Model for Technical Inefficiency Effects in a Stochastic Frontier Production Function for Panel Data. Empirical Economics, 20, 325-332. https://doi.org/10.1007/BF01205442

Battese, G. S., Rao, D., \& O'Donnell, C. J. (2004). A Metafrontier Production Function for Estimation of Technical Efficiencies and Technology Gaps for Firms Operating Under Different Technologies. Journal of Productivity Analysis, 21(1), 91-103. https://doi.org/10.1023/B:PROD.0000012454.06094.29

Baum, C. F., Caglayan, M., \& Talavera, O. (2010). Parliamentary Election Cycles and the Turkish Banking Sector. Journal of Banking and Finance, 34, 2709-2719. https://doi.org/10.1016/j.jbankfin.2010.05.013

Beck, T., Crivelli, J., \& Summerhill, W. (2004). State Bank Transformation in Brazil: Choices and Consequences. Mimeo, The World Bank.

Berger, A. N., \& De Young, R. (1997, June). Problem Loans and Cost Efficiency in Commercial Banks. Journal of Banking \& Financ, 21(6), 849-870. https://doi.org/10.1016/S0378-4266(97)00003-4

Berger, A. N., Hasan, I., \& Zhou, M. (2009). Bank Ownership and Efficiency in China: What Will Happen in the World's Largest Nation?. Journal of Banking and Finance, 33, 113-130. https://doi.org/10.1016/j.jbankfin.2007.05.016

Caprio, G., Laeven, L., \& Levine, R. (2004). Governance and Bank Valuation. Policy Research Working Paper \#3202. The World Bank. https://doi.org/10.1596/1813-9450-3364

Chen, H.-K., Liao, Y.-C., Lin, C.-Y., \& Yen, J.-F. (2108). The Effect of the Political Connections of Government Bank CEOs on Bank Performance During the Financial Crisis. Journal of Financial Stability, 36, 130-143. https://doi.org/10.1016/j.jfs.2018.02.010

Chortareas, G. E., Girardone, C., \& Ventouri, A. (2012). Bank Supervison, Regulation and Efficiency: Evidence from European Union. Journal of Financial Stability, 8(4), 292-302. https://doi.org/10.1016/j.jfs.2011.12.001

Dinç, I. S. (2005). Politicians and Banks: Political Influences on Government-owned Banks in Emerging Markets. Journal of Financial Economics, 77, 453-479. https://doi.org/10.1016/j.jfineco.2004.06.011 
Fries, S., \& Taci, A. (2005). Cost Efficiency of Banks in Transition: Evidence from 289 Banks in 15 Post-communist Countries. Journal of Banking \& Finance, 55-81. https://doi.org/10.1016/j.jbankfin.2004.06.016

Frydman, R., Gray, C., Hessel, M., \& Rapaczynski, A. (1999). Private Ownership and Corporate Performance: Evidence from the Transition Economies. Quaterly Journal of Economics, 114, 1153-1192. https://doi.org/10.1162/003355399556241

Gropper, D. M., Jahera, J. S. Jr., \& Park, J. C. (2015). Political Power, Economic Freedom and Congress: Effects on Bank Performance. Journal of Banking \& Finance, 60, 76-92. https://doi.org/10.1016/j.jbankfin.2015.08.005

Huang, C. J., Huang, T.-H., \& Liu, N.-H. (2014). A New Approach to Estimating the Metafrontier Production Function Based on a Stochastic Frontier Framework. Journal of Productivity Analysis, 42, 241-254. https://doi.org/10.1007/s11123-014-0402-2

Huang, T.-H., Chiang, L.-C., \& Chen, K.-C. (2011, July). An Empirical Study of Bank Efficiencies and Technology Gaps in European Banking. The Manchester School, 79(4), 839-860. https://doi.org/10.1111/j.1467-9957.2010.02178.x

Hung, C.-H. D., Jiang, Y., Liu, F. H., Tu, H., \& Wang, S. (2017). Bank Political Connections and Performance in China. Journal of Financial Stability, 32, 57-69. https://doi.org/10.1016/j.jfs.2017.09.003

Jackowicz, K., Kowalewski, O., \& Kozłowski, Ł. (2013). The Influence of Political Factors on Commercial Banks in Central European Countries. Journal of Financial Stability, 9, 759-777. https://doi.org/10.1016/j.jfs.2012.08.001

Koetter, M., Karmann, A., \& Fiorentino, E. (2006). The Cost Efficiency of German Banks: A Comparison of SFA and DEA. Discussion Paper, Series 2: Banking and Financial Studies. Germany: Deutsche Bundesbank.

Kumbhakar, S. C., \& Wang, H.-J. (2007). Economic Reforms, Efficiency and Productivity in Chinese Banking. Journal of Regulatory Economics, 32(2), 105-129. https://doi.org/10.1007/s11149-007-9028-x

La Porta, R., Lopez-De-Silanes, F., \& Shleifer, A. (2002). Government Ownership of Banks. The Journal of Finance, 57(1), 265-301. https://doi.org/10.1111/1540-6261.00422

Levy-Yeyati, E., Micco, A., \& Panizza, U. (2004). Should the Government be in the Banking Business? The Role of State-Owned and Development Banks. Research Working Paper \# 517. Inter-American Development Bank. https://doi.org/10.1596/1813-9450-3440

Lin, K.-L., Doan, T. A., \& Doong, S.-C. (2016, May). Change in Ownership Structure and Bank Efficiency in Asian Developing Countries: The Role of Financial Freedom. International Review of Economics and Finance, 43, 19-34. https://doi.org/10.1016/j.iref.2015.10.029

McCormick, B. L. (1998). Political Change in China and Vietnam: Coping with the Consequences of Economic Reform. The China Journal, 40, 121-143. https://doi.org/10.2307/2667456

Micco, A., Panizza, U., \& Yañez, M. (2007, January). Bank Ownership and Performance. Does Politics Matter?. Journal of Banking \& Finance, 31(1), 219-241. https://doi.org/10.1016/j.jbankfin.2006.02.007

Nguyen, T. P., Nghiem, S. H., Roca, E., \& Sharma, P. (2016). Bank Reforms and Efficiency in Vietnamese Banks: Evidence Based on SFA and DEA. Applied Economics, 48(30), 2822-2835. https://doi.org/10.1080/00036846.2015.1130788

Phan, T. T., \& Daly, K. (2014). Cost Efficiency and the Relation with Risks in Vietnamese Banking Industry. Australian Journal of Basic \& Applied Sciences, 8(12), 30-38. Retrieved from http://www.ajbasweb.com/old/ajbas/2014/Special\%207/30-38.pdf

Pitt, M. M., \& Lee, L.-F. (1981). The Measurement and Sources of Technical Inefficiency in the Indonesian Weaving Industry. Journal of Development Economics, 9(1), 43-64. https://doi.org/10.1016/0304-3878(81)90004-3

Pradhan, R. P., Arvin, M. B., Hall, J. H., \& Bahmani, S. (2014, November). Causal Nexus between Economic Growth, Banking Sector Development, Stock Market Development, and other Macroeconomic Variables: The Case of ASEAN Countries. Review of Financial Economics, 23(4), 155-173. https://doi.org/10.1016/j.rfe.2014.07.002

Sealey, C. W., \& Lindley, J. T. (1977, September). Inputs, Outputs, and a Theory of Production and Cost at Depository Financial Institutions. The Journal of Finance, 32(4), 1251-1266. https://doi.org/10.1111/j.1540-6261.1977.tb03324.x

Stewart, C., Matousek, R., \& Nguyen, T. (2016). Efficiency in the Vietnamese Banking System: A DEA Double 
Bootstrap Approach. Research in International Business and Finance, 36, 96-111. https://doi.org/10.1016/j.ribaf.2015.09.006

Stiglitz, J. (1993). The Role of the State in Financial Market. Proceedings of the World Bank Annual Conference on Economic Development 1993. The World Bank, Washington, DC. https://doi.org/10.1093/wber/7.suppl_1.19

Sun, L., \& Chang, T.-P. (2011). A Comprehensive Analysis of the Effects of Risk Measurement on Bank Efficiency: Evidence from Emerging Asian Countries. Journal of Banking \& Finance, 35(7), 1727-1735. https://doi.org/10.1016/j.jbankfin.2010.11.017

Vu, T. H., \& Turnell, S. (2010). Cost Efficiency of Banking Sector in Vietnam: A Bayesian Stochastic Frontier Approach with Regularity Constraints. Asian Economic Journal, 24(2), 115-139. https://doi.org/10.1111/j.1467-8381.2010.02035.x

Yin, H., Yang, J., \& Mehran, J. (2013). An Empirical Study of Bank Efficiency in China after WTO Accession. Global Finance Journal, 24, 153-170. https://doi.org/10.1016/j.gfj.2013.07.001

Zhu, N., Wang, B., \& Wu, Y. (2015). Productivity, Efficiency, and Non-performing Loans in the Chinese Banking Industry. The Social Science Journal, 52(4), 468-480. https://doi.org/10.1016/j.soscij.2014.10.003

\section{Notes}

Note 1. Porter, Vietnam, p.p. 75-76.

Note 2. Reuters News Service, 1997/09/30.

Note 3. China Banking Regulatory Commision.

Note 4. The State Bank of Vietnam, 2014/09/30.

Note 5. Cost efficiency measures how well a bank manages its rescources, under the same outputs and specific technical conditions, to achieve the maximum profit at a minimum cost.

Note 6. Because our research just concentrates on banking industry, we decide to drop central banks, securities companies, non-banking credit institutions, and specialized government financial institutions. After that, we continue by deleting all banks which have financial reports less than three years continuously in this period

Note 7. These conditions are tested by doing the Wald test of Marginal effects of outputs and input prices to bank's total cost, Wald test of Shares and Wald test of Hessian Matrix. The results are not shown here to save space.

Note 8 . This process is accomplished by Stata. The detail results are not reported to save space.

Note 9. Note that the cost efficiency points generated by Frontier 4.1 vary from 1 to infinitive, with the value of 1 presents a unique efficiency. Hence, the greater-than-one part in each point is the inefficiency.

Note 10. We use legislative elections.

Note 11. Note that this is the case of cost efficiency. As generated by Frontier 4.1, the minimum value of efficiency score is 1 represents for perfect efficient. Therefore, the more efficiency score, the less cost efficient a bank is.

Note 12. The log likelihood function for the pool data $\ln [\mathrm{L}(\mathrm{Ho})]=-22.835$ and the summation of log likelihood function for the two groups is $\neg \ln [\mathrm{L}(\mathrm{H} 1)]=-329.931$. 